International Journal of Current Advanced Research

ISSN: O: 2319-6475, ISSN: P: 2319 - 6505, Impact Factor: SJIF: 5.995

Available Online at www.journalijcar.org

Volume 6; Issue 4; April 2017; Page No. 3309-3311

DOI: http://dx.doi.org/10.24327/ijcar.2017.3311.0258

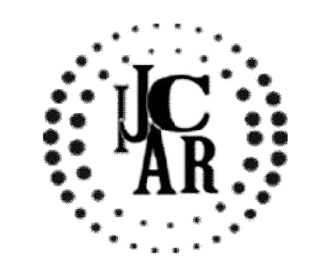

Review Article

\title{
MANAGEMENT OF GUMMY SMILE -A MULTIDISCIPLINARY APPROACH [REVIEW]
}

\author{
Harshini Ravichandran and M G Aarthy
}

Saveetha Dental College and Hospital, Chennai

\begin{tabular}{|c|c|}
\hline A R R I C L E I N F O & A B S T R A C T \\
\hline Article History: & Smile, a person's ability to express a range of emotions with the structure and movement of \\
\hline $\begin{array}{l}\text { Received } 13^{\text {th }} \text { January, } 2017 \\
\text { Received in revised form } 6^{\text {th }} \text { February, } 2017 \\
\text { Accepted } 22^{\text {nd }} \text { March, } 2017 \\
\text { Published online } 28^{\text {th }} \text { April, } 2017\end{array}$ & $\begin{array}{l}\text { the teeth and lips, can often determine how well a person can function in society. A gummy } \\
\text { smile is seen usually when more than } 3 \mathrm{~mm} \text { of gingival is visible. The form and position of } \\
\text { lips during speech and smiling cannot be changed easily, but the dentist can modify the } \\
\text { form of the teeth, interdental papilla, and position of the gingival margin and incisal edges } \\
\text { of the teeth. The therapeutics alternative are often multidisciplinary. The excessive gingival }\end{array}$ \\
\hline $\begin{array}{l}\text { Key words: } \\
\text { Gummy Smile, Multidisciplinary }\end{array}$ & $\begin{array}{l}\text { multidisciplinary approach to manage gummy smile. The aim of this review is to } \\
\text { elucidate the diagnosis, management and therapeutic options for the treatment of } \\
\text { gummy smile. }\end{array}$ \\
\hline
\end{tabular}

Copyright $(2017$ Harshini Ravichandran and $\boldsymbol{M}$ G Aarthy. This is an open access article distributed under the Creative Commons Attribution

License, which permits unrestricted use, distribution, and reproduction in any medium, provided the original work is properly cited.

\section{INTRODUCTION}

A patient's smile can express a sense of joy, success, sensuality, affection, courtesy, and show confidence and kindness. Smile is more than a form of communication; it is kind of socialization and attraction.Patients today no longer consult only for functional reasons but increasingly for esthetic reasons, and notably to increase the beauty of their smile.The main goal of dentists is to achieve an esthetically pleasing smile irrespective of which speciality they belong to. The importance of an attractive smile is priceless. The framework of a smile is formed by the lips, teeth and gingiva. Smile level is an imaginary line that follows the lower margin of the upper lip and usually has a convex appearance. According to Allen, a smile is said to be gummy if more than 2 or $3 \mathrm{~mm}$ of gum is visible during sustained smiling; this is confirmed on forced smiling [1]. Excessive gingival display during smile is considered undesirable and less pleasing, thereby not preferred by the patients. Excessive gingival display is mainly due to dentoalveolar deformities such as short clinical crown due to trauma or carious disease, altered passive eruption, gingival overgrowth and anterior dentoalveolar extrusion. There are also non-dentoalveolar deformities like vertical maxillary excess (VME), short lip and hyperactivity of the upper lip levator muscle.[2] The method for correction of the gummy smile depends on finding the basic cause. It is precisely the etiology of gummy smile associated with its classification that will establish a correct diagnosis, upon which all kinds of treatment will be based. In other words, the various types of treatment and their

*Corresponding author: Harshini Ravichandran

Saveetha Dental College and Hospital, Chennai multidisciplinary nature are respected, having, however, just a single one diagnosis. Thus, this literature review seeks to establish the various treatment alternatives available to correct gum.

\section{Diagnosis}

The first step in establishing a correct diagnosis and a specific plan of treatment is through a proper classification of the gingival level. Unfortunately, available ratings are irregular and use different criteria. In a classic study in this regard, examined 454 young adults and classified them into three categories according to the position of the smile line. The study used the following classification: (1) the smile line is above the cemento-enamel junction (gummy smile); (2) the smile line reveals interproximal gingiva; (3) the smile line displays less than $75 \%$ of upper anterior teeth.[3] Lately, in 1999, 733 peoples were divided as the position of the smile line into four categories: (1) low smile line, in which less than $25 \%$ of interproximal gingiva is visible and there is no margin; (2) average smile line, in which $25-75 \%$ of interproximal gingiva is visible and gingival margins of a single tooth are acceptable; (3) high smile line, in which more than $75 \%$ of interproximal gingiva and gingival margins only are visible; (4) very high smile line, which has a gingival margin of at least $2 \mathrm{~mm}$ continuously visible.[4] More recently, were proposed the following: Class 1 . Very high smile line (gummy smile): more than $2 \mathrm{~mm}$ of apical display or more than $2 \mathrm{~mm}$ of gingival margin to the cementoenamel junction within sound periodontium. Class 2. High smile line: between $0 \mathrm{~mm}$ and $2 \mathrm{~mm}$ of marginal gingiva display or between $0 \mathrm{~mm}$ and $2 \mathrm{~mm}$ of the gingival margin apical to the cementoenamel junction within sound 
periodontium. Class 3. Average smile line: gingival papillae are visible. Class 4. Low smile line: gingival papillae and cemento-enamel junctions are not visible. [5] The comparison between these studies is almost impossible due to striking methodological differences. Besides the classification into different scores, the main ones include the determination of the type of smile (natural/forced) and the state of health of the periodontium. Nevertheless, there is agreement in defining gummy smile as a continuous band of gingival display of more than $3 \mathrm{~mm}$, during spontaneous smile.

The position and amount of teeth and gingival displayed during smile and speech, taking sexual dimorphism and the effects of aging into account, are essential, dynamic and indispensable criteria for the diagnosis and multidisciplinary planning, otherwise the patients' results are uncharacterized because of their age. Two key points must be included during clinical/ photographic examination to determine periodontium visibility. First, the dentist should look not to the marginal gingiva display (the step before smiling), but also gingival display. Secondly, the professional must consider both the natural and forced smiles when evaluating the position of the smile line. When the dentist asks a patient to smile, he or she usually takes cautious reaction and shows a quite natural smile. However, outside the dentist's office, the patient may display a larger portion of the periodontium by forcing a smile to the maximum degree of lip contraction, thereby performing a less esthetic smile. [6-9] That is the reason why some authors such as recommend the use of filming as well as intense and insightful observation of the patient's expression during the initial consultation.[10].

\section{Etiology and Treatment}

Several etiological factors have been proposed, which can be pedagogically divided into dental, gingival, bony, and muscular etiology. On step 1, the presence of the gummy smile is evaluated. On step 2, a clinical occlusal analysis is performed (overbite). On step 3, a gingival excess is analyzed (a. disproportionate crown width and height and gingival excess). One step 4, the bone structure is examined through cephalometric analysis. On step 5, the muscle analysis is conducted (a) lip length (in lateral pictures); (b) muscle tone (in direct front view). When excessive gingival display during smile is derived from dental etiology, there is excessive extrusion of the upper incisors that can be treated with intrusive mechanics. In this case, the problem should be limited to the anterior region.Cases treated with intrusive mechanics based or no on mini implants, with or without periodontal surgery, were reported. [11,12] This, when applied, was used to correct gingival and bone excess located in the anterior region caused by teeth intrusion. a patient with gummy smile caused by gingival grow and accentuated because orthodontic intrusive mechanic to treat excessive overbite, in other words a mix between occlusion and gingival etiology. The disproportionate height and width dimensions of the clinical crown are often indicative of problems associated with excessive gingiva, such as in cases of passive eruption, or in cases of hyperplasic growth. [13] These orthodontic problems are difficult to solve and dentists can do very little in this respect. Nevertheless, during the treatment of associated malocclusions, careful attention must be given to multidisciplinary planning so as to establish the correct time for periodontal treatment.[14]

\section{The Multidisciplinary approach}

The etiologic factors may occur alone or in combination. These include: skeletal problems (dental and bone); gingival disorders (passive eruption and gingival hyperplasia); and muscle problems (upper lip length and muscular hyperactivity). Therapeutic alternatives, in accordance with the underlying etiology, are usually multidisciplinary and multifactorial. [15]The following alternatives are presented in the literature:

- Orthognathic surgery in cases of excessive vertical growth;

- Orthodontic mechanics associated with intrusive mini implants in cases of overbite with extrusion of upper anterior teeth, and additional periodontal surgery to remove excessive gingival tissue and bone volume, resulting from the applied mechanics;

- Periodontal surgery for cases of excessive gingival display or passive eruption;

- Surgery of the muscular tissue for cases of short upper lip;

Use of Botox or surgery of the muscular tissue for cases of hyper contraction of elevator muscles of upper lip.

\section{CONCLUSION}

Patients' requirements are constantly increasing. Therefore, it is essential that treatment planning takes into account not only pre-determined and standardised aspects, but also smile aesthetics in a dynamic way, as well as its relationship with the patient's face. Scientific knowledge and artistic sense is required to understand that smile aesthetics is customized and determined by teeth and gingival display in a frame called lip, which has its size determined by power and size of muscles that are fixed to a rigid bone wall. In addition, awareness and common sense are necessary to understand that this is related to an individual who, according to current beauty standards, may be seeking not just teeth that reproduce the occlusion keys as proposed in the literature, but also a harmonic and balanced face. Thus, a diagnosis and planning with a multidisciplinary understanding is required.

\section{Reference}

1. Vig RG, Brundo GC. The kinetics of anterior tooth display. J Prosthet Dent 1978; 39:502-4.

2. Peck S, Peck L, Kataja M. Some vertical lineaments of lip position. Am J Orthod Dentofacial Orthop 1992; 101:519-24.

3. Tjan AH, Miller GD. The JG. Some esthetic factors in a smile. J Prosthet Dent 1984;51:24-8.

4. Jensen J, Joss A, Lang NP. The smile line of different ethnic groups in relation to age and gender. Acta Med Dent Healv 1999;4:38-46.

5. Liébart MF, Fouque-Deruelle D, Santini A, Laurent F, MonnetCorti V, Jean-Marc G, et al. Smile line and periodontium visibility. $J$ Periodontal Res 2004; $1: 17-25$.

6. Monaco A, Streni O, Marci MC, Marzo G, Gatto R, Giannoni M. Gummy smile: Clinical parameters useful for diagnosis and therapeutical approach. J ClinPediatr Dent 2004; 29:19-25.

7. Reddy PK, Nayak DG, Uppoor A. Aesthetic crown lengthening: A report of 3 cases. Malay Dent J 2006; 
$1: 110-3$.

8. Hwang WS, Hur MS, Hu KS, Song WC, Koh KS, Baik HS, et al. Surface anatomy of the lip elevator muscles for the treatment of gummy smile using botulinum toxin. Angle Orthod 2009; 79:70-7.

9. Kim TW, Kim H, Lee SJ. Correction of deep overbite and gummy smile by using a mini-implant with a segmented wire in a growing Class II Division 2 patient. Am J Orthod Dentofacial Orthop 2006; 130:676-85. 10 .

10. Lin JC, Yeh CL, Liou EJ, Bowman SJ. Treatment of skeletalorigin gummy smiles with miniscrew anchorage. J Clin Orthod 2008; 42:285-96. 11.

11. Ferrario VF, Sforza C, Schimitz JH, Ciusa V, Dellavia C. Digitized three-dimensional analysis of normal dento-labial relationships. Prog Orthod 2001; 2:232-4. 12.
12. Van der Geld P, Oosterveld P, Kuijpers-Jagtman AM. Age-related changes of the dental aesthetic zone at rest and during spontaneous smiling and speech. Eur $J$ Orthod 2008; 30:366-73. 13.

13. Prahl-Andersen B, Ligthelm-Bakker AS, Wattel E, Nanda R. Adolescent growth changes in soft tissue profile. Am J Orthod Dentofacial Orthop 1995; 107:476-83. 14.

14. Ricketts RM. Perspectives in the clinical application of cephalometrics. The first fifty years. Angle Orthod 1981; 51: 115-50. 15 .

15. Polo M. Botulinum toxin type A in the treatment of excessive gingival display. Am J Orthod Dentofacial Orthop 2005;127:214-8.

\section{How to cite this article:}

Harshini Ravichandran and M G Aarthy (2017) ' Management Of Gummy Smile -A Multidisciplinary Approach [Review]', International Journal of Current Advanced Research, 06(04), pp. 3309-3311.

DOI: http://dx.doi.org/10.24327/ijcar.2017.3311.0258 